\title{
Det framtida nordiska hälsosamarbetet
}

\author{
Bo Könberg
}

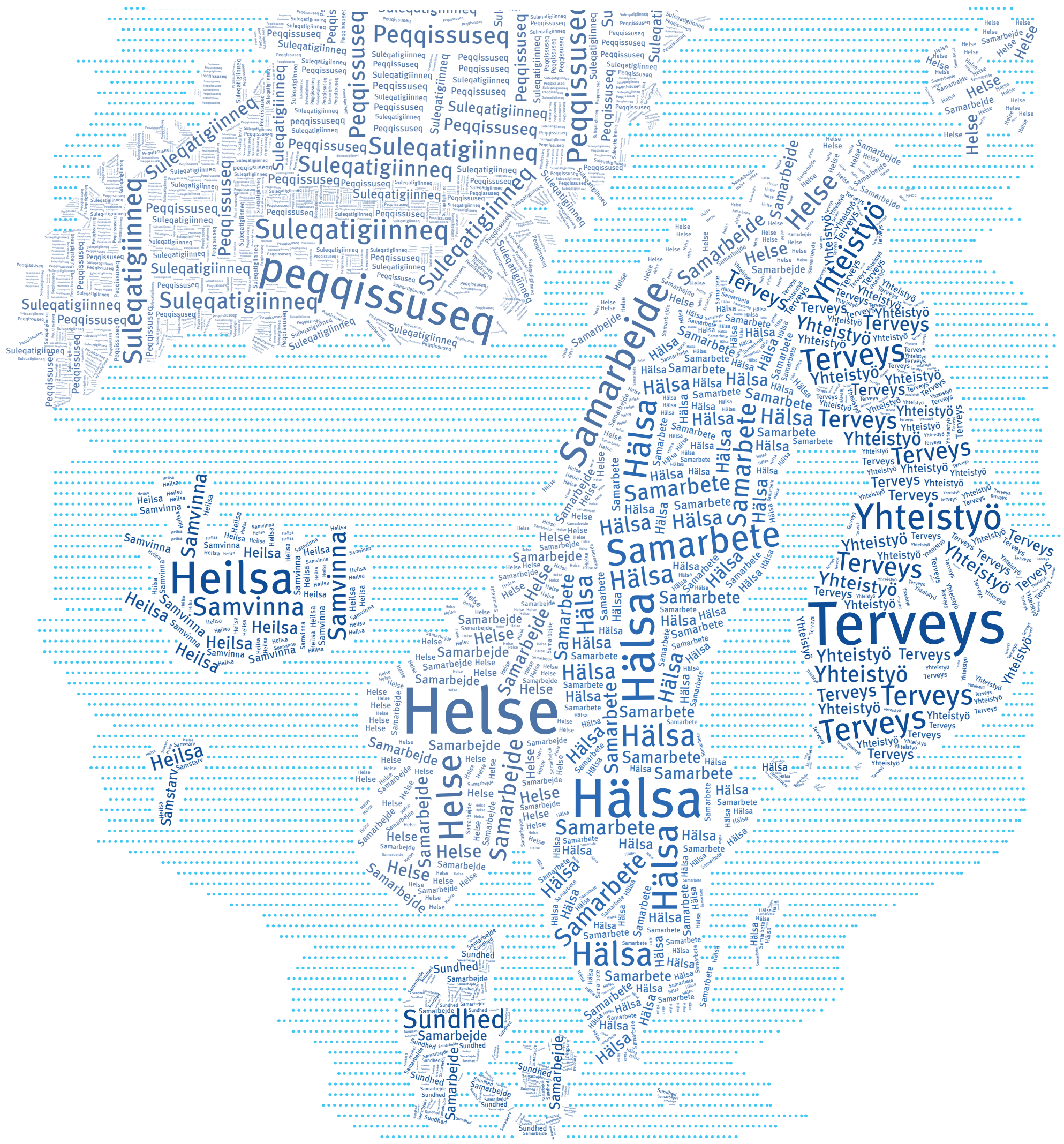




\section{Det framtida nordiska hälsosamarbetet}

ISBN 978-92-893-2806-7

http://dx.doi.org/10.6027/ANP2014-730

ANP2014-730

(C) Nordiska ministerrådet 2014

Layout: Erling Lynder

Tryck: Rosendahls-Schultz Grafisk

Upplaga: 200

Printed in Denmark

Denna rapport är utgiven med finansiellt stöd från Nordiska ministerrådet. Innehållet i rapporten avspeglar inte nödvändigtvis Nordiska ministerrådets synpunkter, åsikter eller rekommendationer.

www.norden.org/sv/publikationer

Nordiska ministerrådet

Ved Stranden 18

DK-1061 Köpenhamn K

Telefon (+45) 33960200

www.norden.org
Det nordiska samarbetet

Det nordiska samarbetet är ett av världens mest omfattande regionala samarbeten. Det omfattar Danmark, Finland, Island, Norge och Sverige samt Färöarna, Grönland och Åland.

Det nordiska samarbetet är politiskt, ekonomiskt och kulturellt förankrat och är en viktig partner i europeiskt och internationellt samarbete. Den nordiska gemenskapen arbetar för ett starkt Norden i ett starkt Europa.

Det nordiska samarbetet ska stärka nordiska och regionala intressen och värderingar i en global omvärld. Gemensamma värderingar länderna emellan bidrar till att stärka Nordens ställning som en av världens mest innovativa och konkurrenskraftiga regioner. 


\section{Det framtida nordiska hälsosamarbetet}

\section{Bo Könberg}

Inledning

Antibiotikaresistens

Förslag 1 Kraftfulla insatser mot den ökande antibiotikaresistensen

Högspecialiserad behandling

Förslag 2 Stärkt samarbete om högspecialiserad behandling i Norden

Sällsynta diagnoser

Förslag 3 Etablera nordiskt nätverk kring sällsynta diagnoser

Registerbaserad forskning

Förslag 4 Ett nordiskt virituellt center för registerbaserad forskning skapas

Folkhälsa och ojämlik hälsa

Förslag 5 Ökat samarbete kring insatser för förbättrad folkhälsa

Förslag 6 En nordisk folkhälsopolitisk plattform för att minska ojämlikhet i hälsa

Patientrörlighet

Förslag 7 Patientrörligheten inom Norden

Hälsa och teknologi

Förslag 8 Förstärkt samarbete om välfärdsteknologi

Förslag 9 Utökat samarbete om eHälsa

Psykiatri

Förslag 10 Stärkt nordiskt samarbete inom psykiatriområdet

Hälsoberedskap

Förslag 11 Utökat mandat för samarbete inom hälsoberedskapsområdet

Läkemedel

Förslag 12 Utbyggt nordiskt läkemedelssamarbete för högre kostnadseffektivitet och bättre säkerhet

Tjänstemannautbyte

Förslag 13 Nytt nordiskt tjänstemannautbyte - Pilotprojekt

Nationella experter i EU

Förslag 14 Nordiskt samarbete om nationella experter i EU-kommissionen 


\section{Inledning}

I slutet av augusti ifjol blev jag tillfrågad av generalsekreteraren i Nordiska ministerrådet och de nordiska hälso- och sjukvårdsministrarna om att ta fram en rapport om förstärkt nordiskt samarbete om hälso- och sjukvård. Förslagen skulle kunna genomföras inom 5-10 år. Som en förebild, bland annat vad gäller upplägg och omfattning av rapporten, fördes fram den uppskattade rapport om nordisk utrikes- och säkerhetspolitik som Thorvald Stoltenberg presenterade i Oslo i februari 2009.

Ministrarna har under tiden vardera utsett två kontaktpersoner: Flemming Møller Mortensen och Sophie Løhde från Danmark, Ulla-Maija Rajakangas och Anne Louhelainen från Finland, Unnur Brá Konrádsdóttir och Árni Páll Árnason från Island, Cecilie Brein-Karlsen och Torgeir Micaelsen från Norge, Lena Furmark och Lena Hallengren från Sverige. Kontaktpersonerna har givit värdefulla synpunkter. Men jag svarar ensam för de 14 förslagen som här presenteras.

Nordiska Ministerrådets seniorrådgivare Astrid Utterström har bistått mig under hela perioden med alla kontakter och med framtagande av rapporten.

Jag har också varit i kontakt med Thorvald Stoltenberg och Sverre Jervell, som var en av sekreterarna som bistod Stoltenberg.

Arbetet med min rapport har bland annat inneburit två resor till vart och ett av de nordiska huvudstäderna, en resa till Färöarna respektive Åland. Mötet med hälsoministern från Grönland ägde rum på Färöarna. Sammantaget har antalet möten överskridit 80 stycken och omfattat ca 250 personer.
Intresset för ett ökat nordiskt samarbete inom hälso- och sjukvården har visat sig stort och jag har haft stor hjälp av alla de synpunkter vi har fått under mötena och vid övriga kontakter.

Hälsan i Norden är god. Den genomsnittliga livslängden i Norden är över 80 år och samtliga fem länderna tillhör de 25-26 med längst livslängd och tre av dem de 10 med längst livslängd. Den snabbt ökande livslängden tycks dessutom bestå av friska år. Spädbarnsdödligheten är bland de lägsta i världen med alla fem länderna bland de 20 med den lägsta och fyra bland de 5-6 lägsta.

Några av mina huvudintryck av mötena och kontakterna är följande:

- Alla nordiska länder vill utvidga och stärka samarbetet på hälsoområdet.

- Det är en utbredd uppfattning att den ökande antibiotikaresistensen kräver krafttag i världen.

- Länderna har visat stort intresse för mer samarbete om högspecialiserad behandling.

- Det är en utbredd uppfattning att länderna bör samarbeta mer och bättre med registerforskning.

- Det är en utbredd uppfattning att den psykiska ohälsan har ökat i Norden, inte minst bland barn och unga.

- Länderna har visat stort intresse för fortsatt och utökat samarbete om ojämlikhet i hälsa.

Utöver ovan nämnda intryck vill jag också lyfta fram två viktiga frågor, antibiotikaresistensen och patientrörligheten. En fråga som tidigt dök upp var hur överanvändning och felanvändning av antibiotika lett till en mycket oroväckande ökning av anti- 
biotikaresistens i världen. Min oro för denna utveckling har därefter enbart ökat och förstärktes ytterligare med den första globala rapport Världshälsoorganisationen (WHO) presenterade för en dryg månad sedan och bekräftades av den rapport som EU:S och USA:S gemensamma organ (TATFAR) för dessa frågor presenterade ett par veckor därefter.

Resistens mot läkemedel blir ett allt större problem i världen, förutom bakterier som utvecklat resistens mot olika typer av antibiotika är även resistenssituationen mycket alarmerande vad gäller läkemedel mot tuberkulos och malaria. Dödligheten i både tuberkulos och malaria har kunnat minskas de senaste decennierna tack vare effektiv medicin men nu sker även en alarmerande ökning av resistenta och multiresistenta tuberkulosbakterier.

Den oroväckande situationen vad gäller antibiotikan och läkemedlen mot tuberkulos och malaria gör det enligt min mening angeläget att frågan behandlas av de nordiska ministrarna på ett möte under hösten.

Patientrörligheten handlar om rättigheten för nordiska medborgare att få vård i ett annat land. Den frågan hanteras bland annat för EU-medlemmarna samt Norge och Island genom EU:s patientrörlighetsdirektiv. Helt nyligen har beslut tagits i de fem nordiska länderna om implementeringen av direktivet. Några erfarenheter om hur implementeringen fallit ut för de nordiska medborgarna har av naturliga skäl ännu inte kunnat vinnas.

Jag har i avvaktan på kunskap om hur de nordiska patienternas rörlighet påverkats av de nya - och delvis olika - reglerna i de fem länderna - stannat för att inte nu föreslå några ytterligare förbättringar utan att föreslå att frågan behandlas på ett ministermöte nästa år.

En central fråga är förstås vilka hälso- och sjukvårdsfrågor som blir bättre omhändertagna genom nordiskt samarbete. Här måste också göras en bedömning av vad som ännu bättre hanteras på europeisk nivå.

Med hjälp av de olika mötena och kontakterna har jag tagit fram 14 konkreta förslag. De har utformats så att alla nordiska länderna ska kunna vara med. Det kan dock ibland vara så att 3-4 länder går vidare och andra kan ansluta senare eller eventuellt inte alls.

Reykjavik den 11 juni 2014 4 . Bo Könberg 


\section{Antibiotikaresistens}

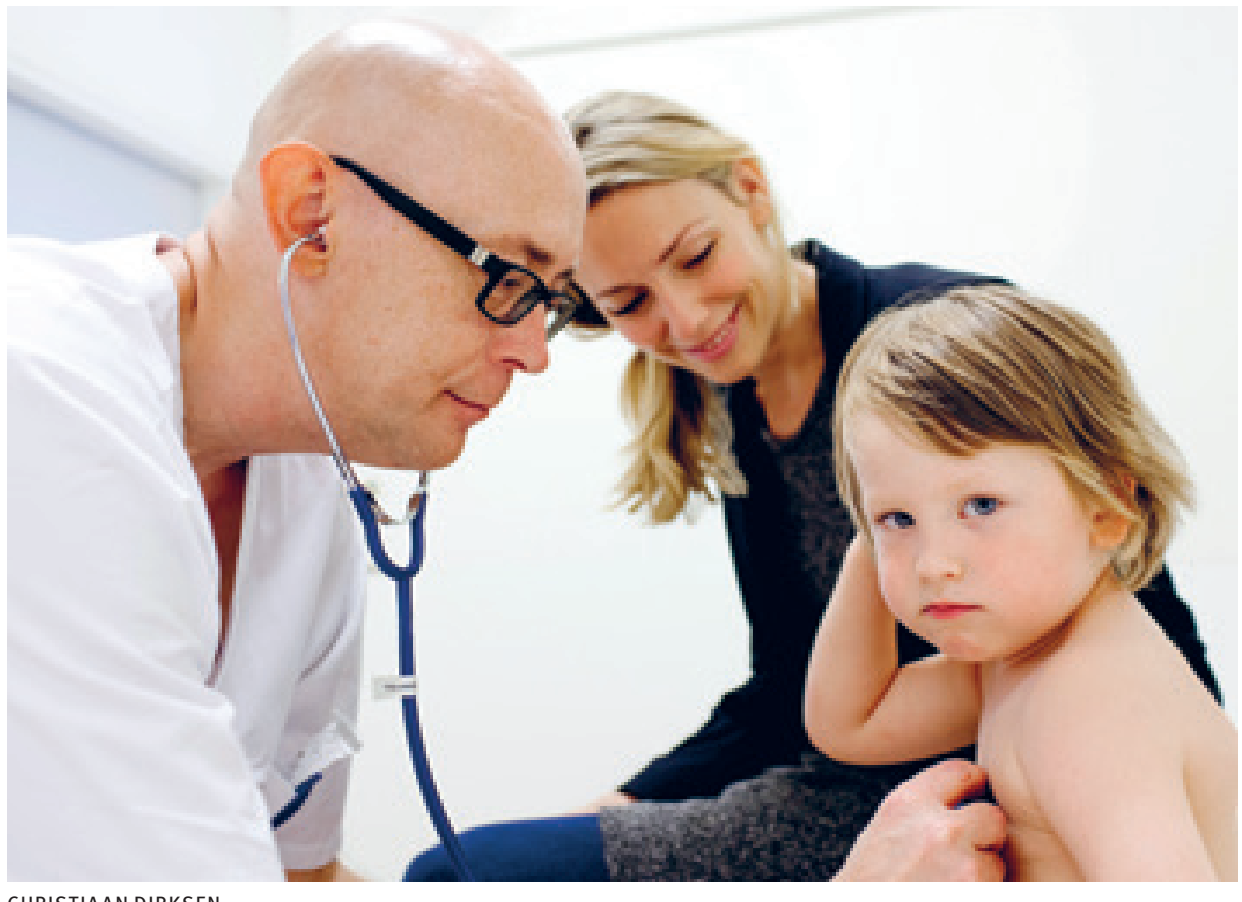

\section{Förslag 1}

\section{Kraftfulla insatser mot den ökande antibiotikaresistensen}

Norden bör målmedvetet driva frågan om kraftfulla insatser mot den ökande antibiotikaresistensen och resistensen mot medel mot tuberkulos och malaria. Trots att de nordiska länderna i genomsnitt har lägre antibiotikaanvändning än resten av Europa, och förstås själva svarar för en mycket låg andel av världsproblemet, måste de sätta upp egna mål att snabbt - inom kommande 5 år minska konsumtionen av antibiotika till den lägsta europeiska nivån, som nu är den nederländska.

Vidare måste de nordiska länderna inom EU, WHO och FN verka för ett snabbt genomförande av ett program mot dagens orimligt höga användning av antibiotika för att stärka system och samarbetsstrukturer som kan bidra till utveckling av ny antibiotika samt för belöningar för fram- tagande av ny antibiotika. Tre punkter i programmet börvara:

- Införande av recepttvång i de länder med sådant utvecklat hälsosystem att detta är möjligt och stopp för bonus till läkare och sjukhus som skriver ut 
antibiotika. Även stopp för veterinärer att själva sälja den antibiotika de skriver ut.

- Alla länder bör införa regler och mål för att minska den egna användningen.

- Stärka incitamenten för utveckling av ny antibiotika. De rika länderna bör under de kommande 5 åren årligen sätta av 15 miljarder SEK för att stärka system och samarbetsstrukturer som kan bidra till utveckling av ny antibiotika, och för belöningar till dem som uppfinner och utvecklar nya sådana läkemedel.

En av de största uppfinningarna under 1900-talet är upptäckten och det industriella tillverkandet av penicillinet och andra antibiotika mot bakterier i människokroppen. Upptäckten gjordes för drygt 80 år sedan. Upptäckten fick 1945 Nobelpriset i medicin. I sitt tacktal varnade en av pristagarna, Sir Alexander Fleming, för risken att en framtida överanvändning skulle kunna leda till att antibiotikan blev verkningslös.

En sådan överanvändning och åtföljande ökad resistens mot antibiotika pågår sedan länge. I Europa avled ifjol minst 25000 människor av att resistensen mot antibiotika sprider sig. Antalet avlidna i trafiken i Europa var samma år detsamma. I USA beräknades häromveckan motsvarande siffra till över 23000 personer. Till detta kommer att upptäckter av nya antibiotika i praktiken har upphört. Fram till 1970 tillkom ett tjugotal antibiotika. Sedan dess har två nya tillkommit, varav ingen efter 1987 !

Och såvitt känt är väntar inga upptäckter runt hörnet. Beskedet till oss idag är att det inte finns några nya i pipeline och med nuvarande utveckling är sannolikheten låg att några nya kommer inom de närmaste tio åren!

Resistens mot antibiotika leder till stora problem inom sjukvården eftersom modern sjukvård är helt beroende av antibio- tika. Det som börjat hända, och vi kommer se alltmer i framtiden, är en ökad dödlighet i infektioner. Det gäller både av skador som sår eller trafikolyckor, och även av infektioner som lunginflammation eller urinvägsinfektion som vi idag betraktar som ofarliga eftersom de kan behandlas med antibiotika. Många transplantationer och operationer kommer att bli omöjliga eller mycket riskfyllda, eftersom man vid operationer ger antibiotika både i förebyggande syfte och efter ingreppet. Vid sjukdomar som försvagar immunförsvaret, som cancer eller hiv, är det oftast en infektion som inte kan hävas som är dödsorsaken.

Denna mycket oroväckande utveckling har uppmärksammats sedan tidigare, bland annat av WHO för drygt 10 år sedan, men trots detta har långtifrån tillräckliga åtgärder vidtagits. I slutet av april presenterade WHO sin första globala rapport om det ökande antimikrobiella motståndet mot antibiotika och mot tuberkulosläkemedel och malarialäkemedel. Innehållet är mycket alarmerande. Ett par veckor senare presenterade EU:S och USA:S gemensamma organ (TATFAR) också en rapport om den oroväckande utvecklingen.

Utöver resistensen mot antibiotika är resistensen även mycket alarmerande vad gäller läkemedel mot tuberkulos och malaria. Dödligheten i både tuberkulos och malaria har de senaste decennierna kunnat minskas tack vare effektiv medicin, men nu sker även en snabb ökning av resistensen mot dessa mediciner.

Det borde nu vara uppenbart för alla att synnerligen snabba åtgärder måste vidtas för att minska förbrukningen och därmed ge oss något mer tid då vi måste få fram nya antibiotika samt påskynda detta genom att se till att det finns kraftiga ekonomiska incitament för att ta fram dessa.

Överkonsumtionen i Norden och övriga Europa är med all sannolikt mindre än i Kina, Indien och USA, men måste förstås ändå minskas - både som bidrag till minskad 
ökningstakt i resistensen och för att med större kraft kunna påverka den övriga världen att minska sin konsumtion.

Ett vanligt sätt att mäta omfattningen är antalet doser per dygn och tusen invånare. Av diagrammet framgår att skillnaderna mellan de europeiska länderna är mycket stora - alltifrån Turkiets med 42 till Nederländernas med 11. Landet med den hög- sta användningen i Europa använder alltså 3,5 gånger mer antibiotika än landet med den lägsta!

Större delen av Norden har en nivå som är lägre än det europeiska genomsnittet med Sverige strax ovanför den nederländska nivån. Ändå är skillnaden mellan Sverige och det nordiska land som har den högsta nivån - Island - så stor som drygt 50 \%.

\section{Antibiotikaförbrukning 2011 utanför sjukhusen}

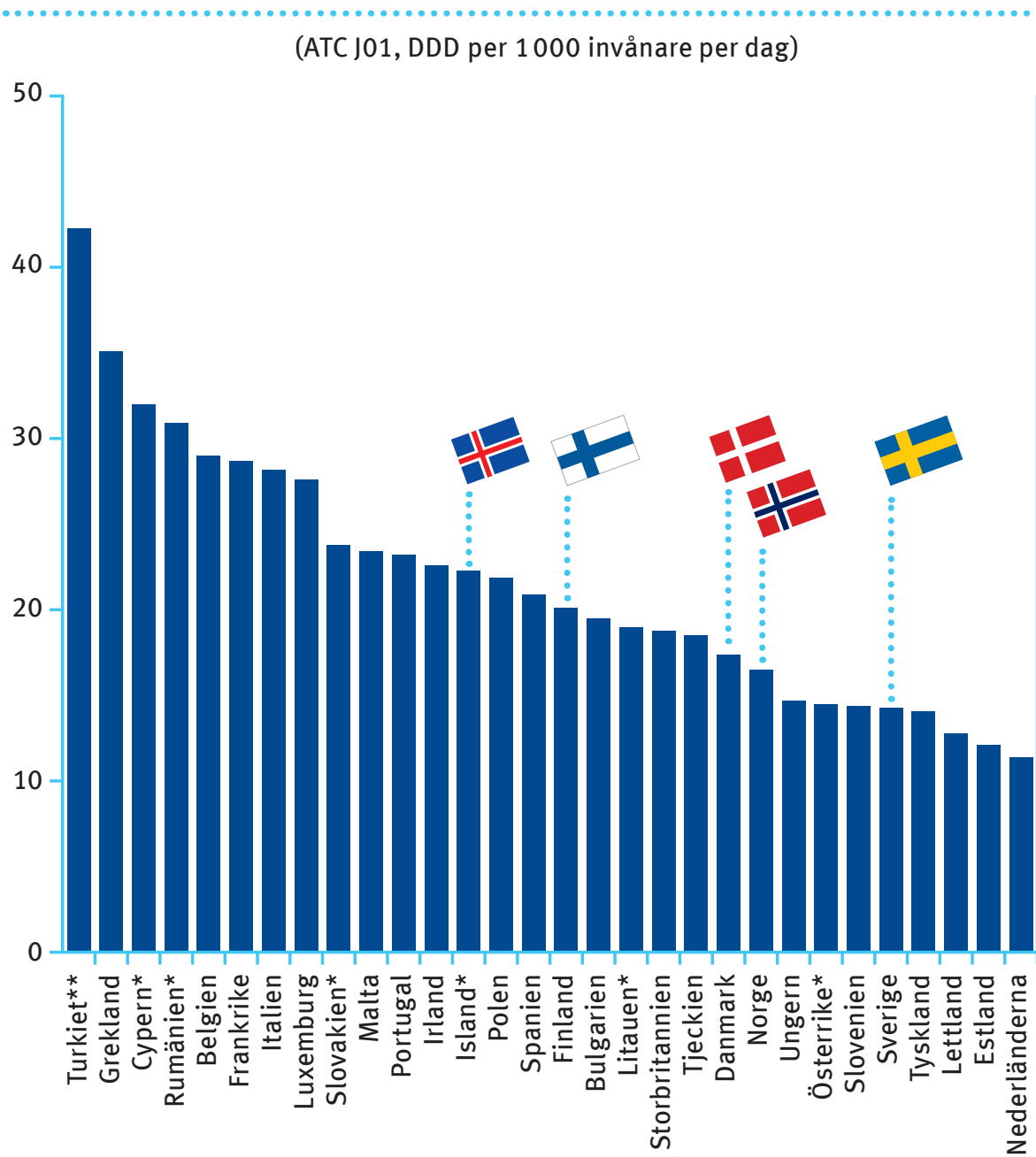

Källa: European Centre for Disease Prevention and Control (ECDC), Consumption of antimicrobials of Antibacterials For Systemic Use (ATC group J01) in the community (primary care sector) in Europe, reporting year 2011

*ECDC: Siffran anger totalförbrukning, inklusive sjukhusvården.

**Källa: The Lancet Infectious Disease, Vol 14 May 2014, Antibiotic use in eastern Europe: a cross-national database study in coordination with the WHO Regional Office for Europe. Siffran anger totalförbrukning, inklusive sjukhusvården. 
En rimlig ambition för minskningen i Norden är att inom en femårsperiod komma ned till dagens nederländska nivå.

Flera länder, däribland Turkiet, har antagit planer för att minska sin överanvändning av antibiotika. Ett annat exempel är Indien som antog den så kallade Chennaideklarationen 2012, en femårsplan för att bekämpa antibiotikaresistens.

Utöver överanvändningen av antibiotika för människor används mycket antibiotika även inom djurhållningen. Den används både mot bakterier, men också av kommersiella skäl, för att öka tillväxten av djurköttet. Inom EU är den senare användningen inte längre tillåten, men att ge i förebyggande syfte mot sjukdomar är tillåtet och där är gränserna något vaga. Ett exempel på framgångsrik minskning av antibiotikan till djur står Sverige för. I Sverige har användningen av antibiotika till djur de senaste sex åren minskat med drygt 1/3 till vad som troligen är den lägsta nivån i EU. Detta har skett genom åtgärder för bättre djurhållning och hygien. Användningen i Island och Norge är ännu lägre.

Trots gemensamma regler i EU för hur antibiotika ska ges till djur finns det fortfarande stora skillnader mellan länderna. Veterinärer kan i vissa medlemsstater i EU själva sälja den antibiotika som de skriver ut. Detta kan leda till fler förskrivningar och överförskrivningar vilket bör sättas stopp för. Ett förbud mot att veterinärer tjänar pengar på försäljning av antibiotika bör införas i EU.

Skillnaden mellan EU-länderna vad gäller användningen av antibiotika i djurhållningen är också mycket stor. Det finns länder som häromåret använde 30 gånger så mycket antibiotika per kg kött som det EU-land som använder minst, Sverige.

Ett positivt exempel från i år är att Nordiska ministerrådet tagit initiativ till att säk- ra "One Health" perspektivet i det nordiska samarbetet genom att tillsätta en ny arbetsgrupp för att samarbeta om antibiotikaresistensen.

Bland de direkta åtgärder de nordiska länderna bör vidta är förbättrade rutiner och hygien inom sjukvården och det nämnda uppsättandet av 5-årsmålet att minska den totala användningen av antibiotika inom sjukvården till dagens nederländska nivå.

Inom EU, WHO och FN bör man kraftfullt verka för att alla länder sätter upp mål för minskning av överanvändningen av antibiotika till människor och djur samt att kraftfulla ekonomiska incitament sätts upp för framtagandet av nya antibiotika. Norden bör ta på sig ledartröja för att driva denna fråga.

Även inom ramen för de nordiska ländernas bistånd till utvecklingsländerna bör frågan om överanvändning av antibiotika tas upp.

Åtgärder har på senare år vidtagits inom EU för att ekonomiskt och på andra sätt stimulera innovationer på antibiotikaområdet. De är dock långtifrån tillräckliga.

Det finns uppenbarligen betydande vetenskapliga problem med att ta fram ny antibiotika. En viktig orsak till att inte några nya antibiotika tas fram är sannolikt att de nuvarande ekonomiska incitamenten för detta är för svaga eftersom syftet är att de nya läkemedlen ska användas sällan och därmed ge mindre inkomster än läkemedel som används ofta.

För att lösa problemet med att få fram nya antibiotika kommer det med all sannolikhet krävas många tiotals miljarder SEK. Dessa pengar måste avsättas av de rika länderna. Mitt förslag är därför att EU, USA och övriga rika länder överenskommer att under de kommande 5 åren varje år sätter av ca en tjugondedels promille av deras BNP till stöd för framtagande av nya 
antibiotika, samt belöningar för dem som lyckas få fram dem, samt därmed överta äganderätten till dessa och därmed kunna förskriva villkor för ländernas användning av de nya preparaten.

För Norden motsvarar detta ca en halv miljard årligen och för EU, USA och övriga rika länder ca 15 miljarder SEK, och då på 5 år ca 75 miljarder SEK. Hur mycket av detta som ska anslås direkt till forskning och hur mycket belöning/pris till dem som presenterar nya antibiotika får prövas närmare.

Mot bakgrund av ovanstående förslag, föreslås att frågan tas upp till behandling på ett ministermöte under hösten 2014. 


\title{
Högspecialiserad behandling
}

\section{Förslag 2 $\quad$ Stärkt samarbete om högspecialiserad behandling i Norden}

\author{
En nordisk beredningsgrupp etableras på hög nivå som \\ ska stärka och vidareutveckla det nordiska samarbetet \\ om högspecialiserad behandling inom hälso- och sjuk- \\ vården.
}

De nordiska länderna har många gemensamma drag, vilket gör att ett samarbete om högspecialiserad behandling känns självklart. Hälso- och sjukvården i de nordiska länderna genomgår en betydande centralisering. Förutom språkliga och kulturella likheter har alla de nordiska länderna även relativt små populationer, sjukdomsmönster och klinisk praxis liknar varandra.

Därför pågår det redan nu många bra samarbeten om högspecialiserad behandling i Norden. Detta arbete ska dock konsolideras och vidareutvecklas, så att samarbetet bättre förverkligar de inneboende möjligheter som finns för att bidra till effektivitet, kvalitet och god användning av de ekonomiska resurserna i länderna.

För att konsolidera samarbetet och stötta ländernas strategiska bedömning av var det finns potential för ett nordiskt samarbete, bör en beredningsgrupp för högspecialiserad behandling i Norden etableras. Beredningsgruppen ska stötta länderna i deras kontinuerliga bedömning av var de kan skapa vinster genom att delta i ett nordiskt samarbete om konkreta högspecialiserade behandlingar, till exempel genom att samarbeta om inköp av dyr teknologi samt underlätta arbetet med att sjösätta nya samarbetsinitiativ.

Beredningsgruppens huvudsakliga uppgift ska vara att fungera som ett forum för en regelbunden dialog mellan länderna om behoven och möjligheterna för samarbetsinitiativ på området. Det enskilda landet ska informera beredningsgruppen när en ny, högspecialiserad behandlingsinsats planeras. Detta ger beredningsgruppen möjlighet att diskutera om ett nordiskt samarbete kan skapa vinster för den aktuella insatsen ifall liknande behov - eller erfarenheter på området - finns i ett eller flera av de andra nordiska länderna. Det enskilda landet ser till att dialogen i beredningsgruppen görs så tidigt i planeringsfasen att det finns möjlighet att påbörja ett samnordiskt samarbete där det är relevant. Hinder i regelsystemen för att öka det nordiska samarbetet om högspecialiserad vård tas bort.

Beredningsgruppen ska som en del av diskussionerna om relevanta samarbetsinitiativ diskutera förutsättningarna för initiativens genomförande, bland annat kontinuerligt klarlägga vilka hinder i lagstiftningarna som ska lösas för att skapa en grund för effektiva, nordiska samarbeten om högspecialiserad behandling. Beredningsgruppen ska dessutom kontinuerligt diskutera vad länderna emellan ska förstå som högspecialiserad behandling. Beredningsgruppen bygger vidare på de erfarenheter som skapats genom befintliga, nordiska samarbeten, bland annat initiativet om högspecialiserad behandling i regi av Nordiska ministerrådets program om Hållbar nordisk välfärd. 
Beslut om samarbeten ska i större utsträckning ingå i ländernas strategiska planering av nya initiativ och vara förankrade nära den politiska nivån. Medlemmarna i beredningsgruppen ska därför finnas på hög nivå. Beredningsgruppen ska knytas till Nordiska ministerrådet för social- och hälsopolitik och få sitt mandat från ministerrådet. 


\section{Sällsynta diagnoser}

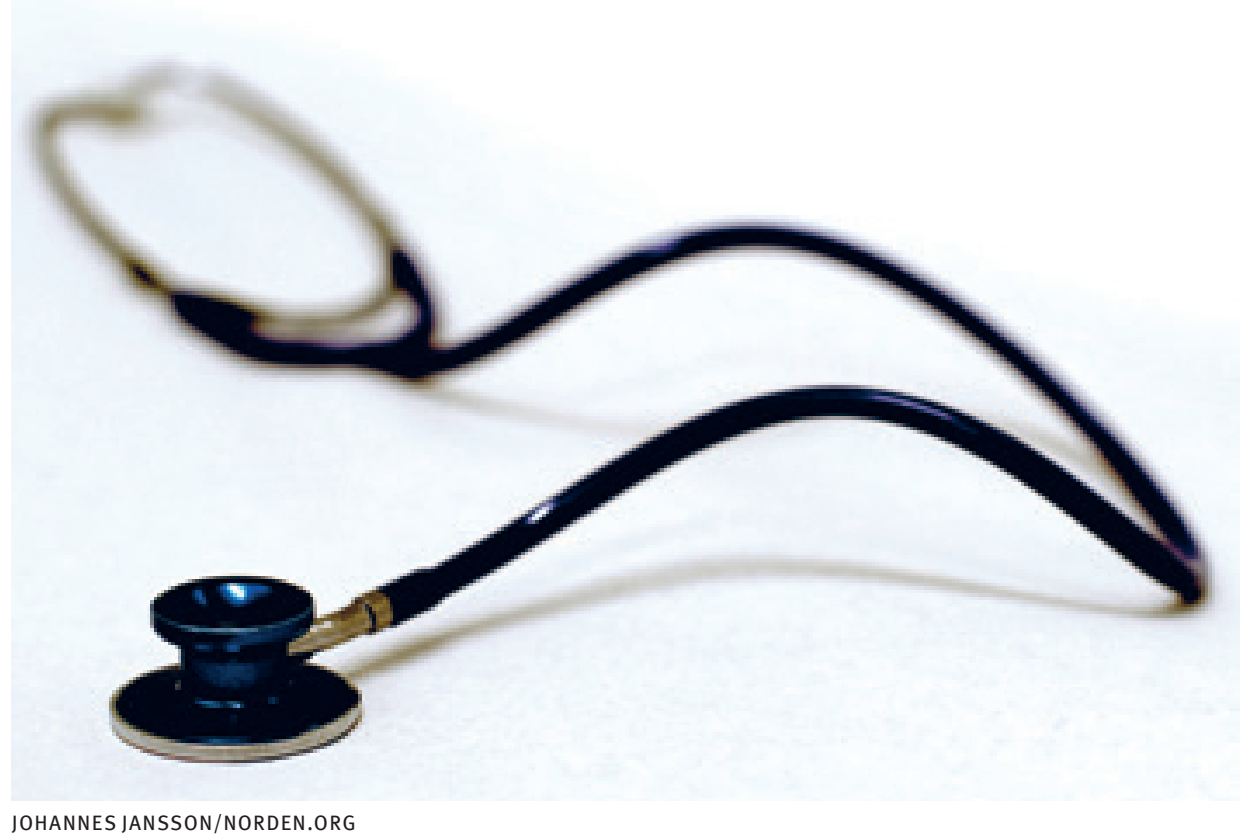

\section{Förslag $3 \quad$ Etablera nordiskt nätverk kring sällsynta diagnoser}

\section{Ett nordiskt nätverk om sällsynta diagnoser ska upprättas.}

De nordiska ländernas befolkningar är relativt små och därför är det en utmaning att få ett tillräckligt stort befolkningsunderlag för att utveckla och upprätthålla expertisen vad gäller insatsen för människor med sällsynta diagnoser. De nordiska länderna har sammanlagt dock cirka 26 miljoner invånare och ländernas gemensamma drag gör att ett nordiskt samarbete känns självklart, något som ska stärka det enskilda landets kunskapsmiljöer om och insats för människor med sällsynta diagnoser.

De nordiska länderna har under flera år inlett olika samarbeten om sällsynta diagnoser, till exempel samarbetet om informationsutbyte via Rarelink. Dessa samarbeten ska utvecklas, men det är även viktigt att stärka de pågående och nya gemensamma nordiska insatserna och att samordna dem bättre.

Länderna bör därför upprätta ett nordiskt nätverk för ett framåtriktat samarbete på området för sällsynta diagnoser som kan säkra den kontinuitet som behövs i arbetet. På så sätt får det nordiska samarbetet inom området en större effekt för de relevanta ämnesmiljöerna och myndigheterna i länderna - och slutligen även för invånarna. 


\title{
Registerbaserad forskning
}

\section{Förslag $4 \quad$ Ett nordiskt virituellt center för registerbaserad forskning skapas}

\author{
Det nordiska forskningssamarbetet kring dataregister, \\ biobanker och kliniska interventionsstudier ska stärkas \\ genom att underlätta tillgången till våra unika nordiska \\ datakällor i forskning. En modell för ömsesidigt erkän- \\ nande av etikprövningar för nordiska forskningsprojekt \\ ska införas. Ett sådant samarbete kan bidra till att ut- \\ veckla forskning, näringsliv och välfärd i Norden.
}

Det nordiska forskningssamarbetet kring dataregister, biobanker och kliniska interventionsstudier ska stärkas genom att underlätta tillgången till våra unika nordiska datakällor i forskning.

En modell för ömsesidigt erkännande av etikprövningar för nordiska forskningsprojekt ska införas. Ett sådant samarbete kan bidra till att utveckla forskning, näringsliv och välfärd i Norden.

Norden är en guldgruva för populationsbaserad forskning på grund av tillgången till lagrade individdata i administrativa personregister och biobanker. Denna information har samlats in under lång tid och täcker ofta hela befolkningen $i$ Norden. Likheterna mellan de nordiska ländernas hälso- och välfärdssystem samt våra personnummer innebär goda förutsättningar för jämförande studier och analyser i Norden. Tillsammans har Norden 26 miljoner invånare vilket utgör ett befolkningsunderlag som möjliggör studier av ovanliga sjukdomar.

Ökad användning av registerdata i forskning kan bidra till att förebygga sjukdomar, hitta effektivare läkemedel och vidareutveckla behandlingsmetoder till exempel inom individualiserad sjukvård. Åtgärder för att stärka det nordiska samarbetet inom detta område kommer att öka antalet kliniska studier och därmed bidra till att ge ett bättre kunskapsunderlag för politiska prioriteringar inom välfärdssektorn samt öka konkurrenskraften hos näringslivet. Norden skulle dessutom stärka sitt varumärke som en attraktiv region för att bedriva toppforskning.

För att kunna använda den data som finns krävs emellertid följande åtgärder:

Länderna måste undanröja praktiska, juridiska och etiska hinder för gemensam användning av data för forskning. Nationella dataägare med ansvar för administrativa personregister, biologiska data (sjukvårdens kvalitetsregister, biobanker) eller liknande bör samarbeta för att förenkla användande och överföring av data över gränser.

En modell för ömsesidigt erkännande av etikprövningar för nordiska forskningsprojekt ska införas.

Vidare bör länderna arbeta för att underlätta användandet av personuppgifter i gränsöverskridande forskning under gäl- 
lande lagstiftning, till exempel genom ändrad praxis. Länderna bör också undersöka möjligheter till nordisk synergi, i synnerhet i relation till kommande europeisk lagstiftning inom dessa områden.

Forskningsinfrastrukturen ska förstärkas inom dessa områden. NordForsk och forskningsråden (eller motsvarande) bör stödja utvecklingen av tekniska lösningar som möjliggör säker överföring, lagring och tillgång till personuppgifter och forskningsdata även över gränserna. Förutom enklare samordning av data bör det också möjliggöras för uppbyggnad av gemensamma nordiska datakällor/register. Därutöver bör NordForsk och forskningsråden finansiera forskning och utbildning på nordisk nivå för att utnyttja de gemensamma nordiska datakällorna. Vissa förberedande åtgärder har redan vidtagits av NordForsk.
När praktiska, juridiska och etiska hinder är undanröjda bör satsningarna på forskningsinfrastruktur och forskning vidareutvecklas till inrättandet av ett nordiskt virtuellt center för registerbaserad forskning. Ett sådant center skulle möjliggöra att våra unika dataregister och biobanker kan användas av forskare och företag som en gemensam nordisk resurs genom att utgöra en samarbetsplattform för nationella aktörer, och fortsätta arbetet för att undanröja existerande hinder för gränsöverskridande forskning. En sådan gemensam distribuerad nordisk resurs kan koordineras av NordForsk, till exempel baserat på en modell liknande den för det nordiska e-infrastruktur samarbetet (NeIC), i nära samarbete med centrala nationella aktörer. 


\title{
Folkhälsa och ojämlik hälsa
}

\section{Förslag 5 Ökat samarbete kring insatser för förbättrad folkhälsa}

\author{
De nordiska länderna bör öka erfarenhetsutbytet i folk- \\ hälsofrågorna, främst vad gäller bruket av tobak och \\ missbruket av alkohol.
}

Tobak och alkohol är två socialt accepterade stimulantia i stora delar av världen, trots att dessa bidrar till sämre folkhälsa. Norden har generellt en lägre alkoholoch tobakskonsumtion än i övriga Europa, men kan arbeta ännu mer aktivt för att minska tobaks- och alkoholrelaterade sjukdomar, inte minst cancersjukdomar. De nordiska länderna bör besluta att tätare utbyta erfarenheter inom folkhälsoområdet, främst vad gäller medel inom alkoholpolitiken och tobakspolitiken.

Det finns mycket att göra för en förbättrad folkhälsa i Norden trots den kraftiga ökningen av livslängden och att det som nämnts i inledningen till rapporten dessutom förefaller vara friska år som läggs till livet. De två viktigaste områdena, och som dessutom kan påverkas av politiska beslut, är bruket av tobak och missbruket av alkohol.

\section{En jämförelse av den nordiska tabellen} över livslängd och tabellen över konsumtionen av alkohol och tobak tyder på att det finns samband.

Ett exempel är antalet lungcancerfall per miljon invånare, som varierar kraftigt mellan de olika länderna. År 2011 var antalet fall i Danmark drygt 800 och i Sverige knappt 400.

\section{Förväntad livslängd}

2012

Ökning (i år) 1960-2012*

Island

82,9

9

Sverige

81,7

9

Norge

81,5

8

Finland

80,6

12

Danmark

80,1

8

Norden i snitt

81,4

9

Data: World Bank 2012

*avrundat till närmaste heltal 


\section{Män som röker dagligen}

\section{(i \% av män från 15 år och äldre)}

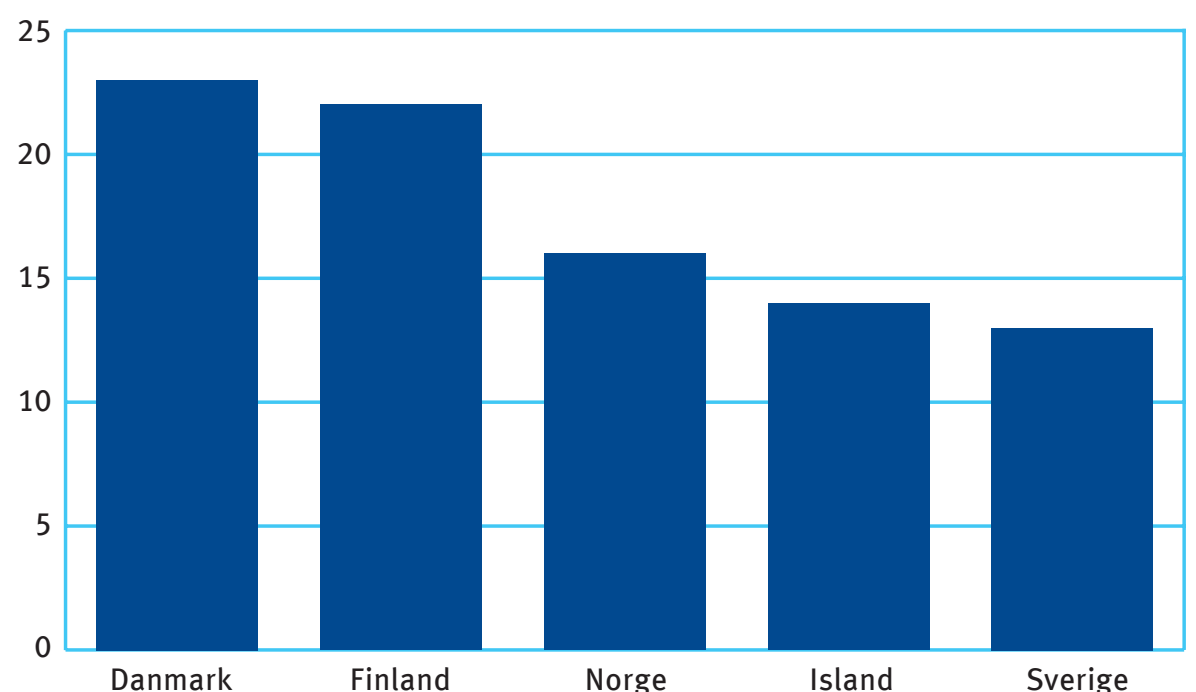

Källa: Helsestatistik for de nordiska lande 2013 (Nomesko), s. 44, tabell 3.1.2 Daglige rygere procentvis efter køn

För DK ålder 16+, FIN 15-64 år, NO 16-74 år, IS 15+, SVE 16-84

Försäljning av alkoholdrycker i liter $100 \%$ ren alkohol per invånare

(15 år och äldre)

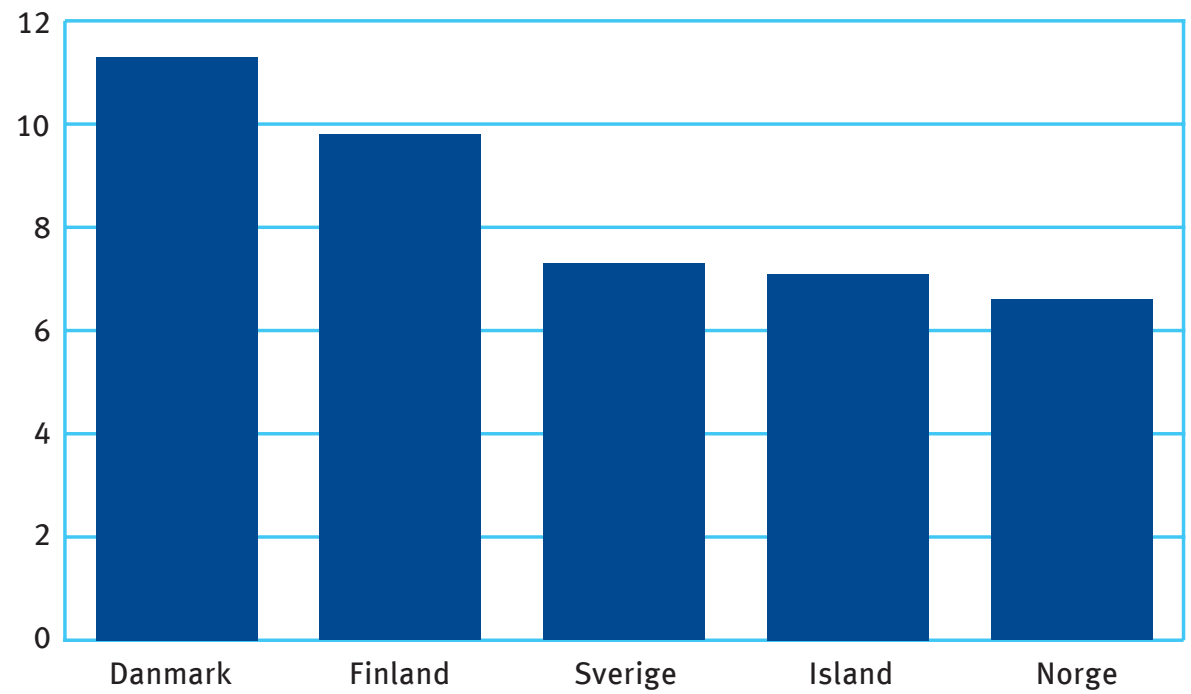

Källa: Helsestatistik for de nordiska lande 2013 (Nomesko), s.47, tabell 3.1.4 Salg av alkoholiske drikke i liter 100 pct ren alkohol pr. indbygger 15 år og derover

För FIN \& NO är talen från 2011, DK och SE från 2010 och IS 2005. 


\section{Självangiven fetma, män}

(i \% från åldern 15 och äldre)

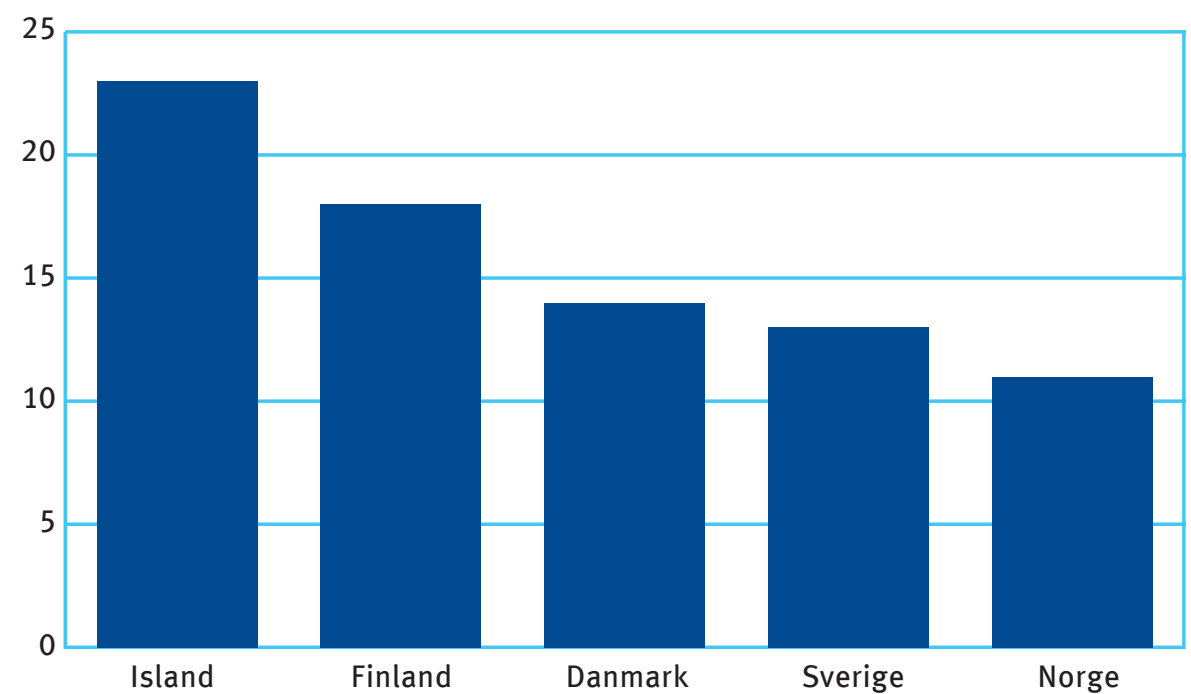

Källa: Helsestatistik for de nordiska lande 2013 (Nomesko), s.44, tabell 3.1.1: Oversigt over selvrapporteret fedmerate, indbyggere i alderen 15 år og derover

Med fetma menas BMI 30. För NO räknas från åldern 16+

De nordiska länderna bör besluta att tätare utbyta erfarenheter inom folkhälsoområdet, främst vad gäller medel inom alkoholpolitiken och tobakspolitiken. Ett syfte bör vara, att med hjälp av de olika ländernas erfaren- heter bringa ned alkoholkonsumtionen och tobakskonsumtionen. Länder och områden med låga åldersgränser för inköp av alkohol och höga promillegränser i trafiken bör ta del av de andra ländernas erfarenheter. 


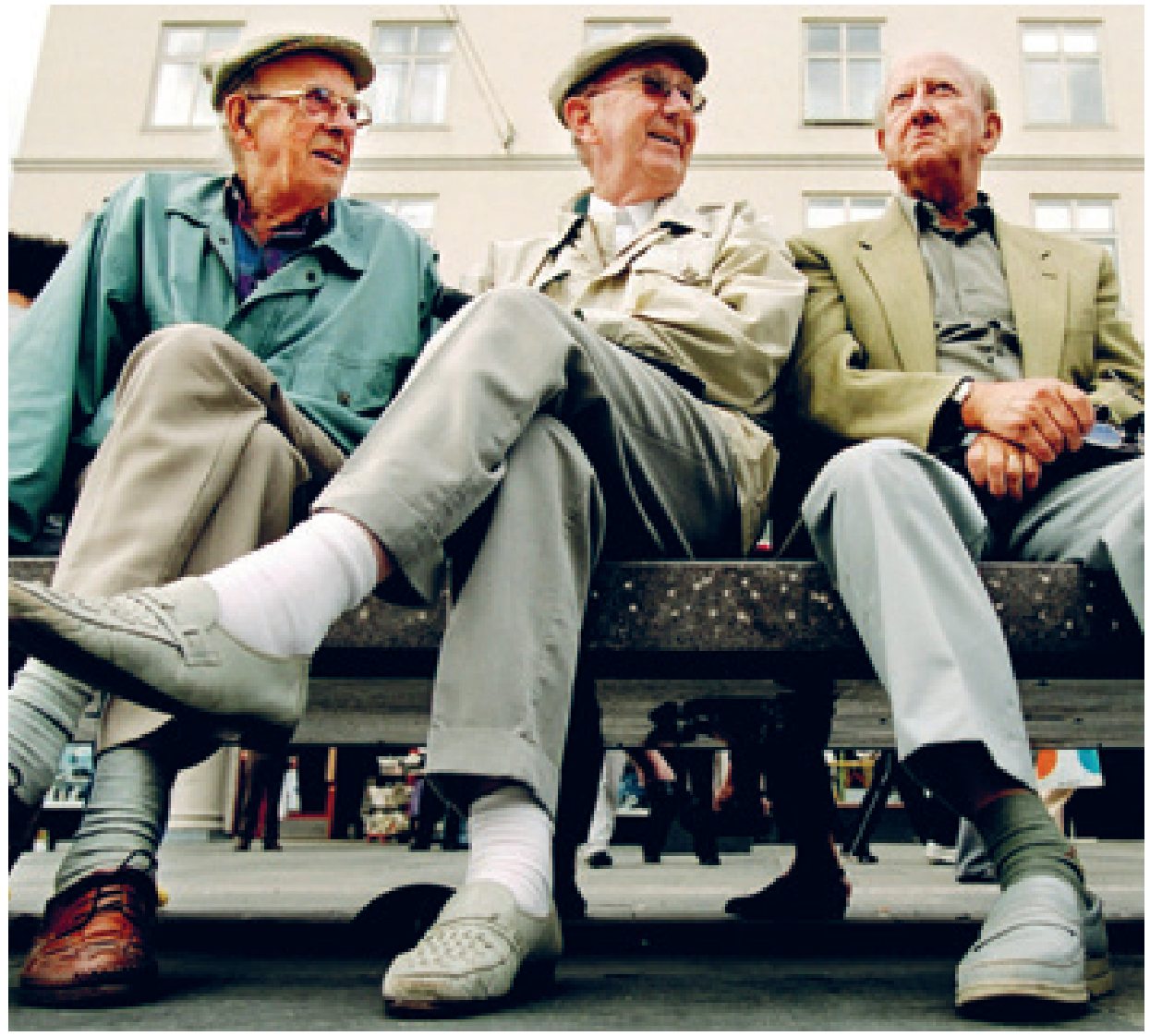

KAREN BEATE NøSTERUD/NORDEN.ORG

\title{
Förslag 6
}

\section{En nordisk folkhälsopolitisk plattform för att minska ojämlikhet i hälsa}

\author{
En nordisk folkhälsopolitisk plattform ska etableras \\ med uppgiften att ta fram förslag till nordiska projekt \\ och aktiviteter med målet att minska ojämlikhet i hälsa.
}

I Norden har folkhälsan utvecklats positivt under många år. Den nordiska välfärdsmodellen med relativt låga ekonomiska standardskillnader ger goda förutsättningar att utjämna skillnader i hälsa. Ändå är hälsoskillnaderna i Norden betydande mellan dem med lång utbildning och hög inkomst och dem med kort utbildning och låg inkomst. En stor utmaning för den nordiska välfärden är alla de kroniska sjukdomar som beror på livsstilen. En bättre hälsa ger många samhälleliga vinster; minskad sjuklighet och dödlighet, högre livskvalitetet och större välbefinnande för alla nordbor. Det är därför hög tid att vända trenden med ökande skillnader i hälsa genom en kraftsamling på nordisk nivå.

En nordisk folkhälsopolitisk plattform skapas och får uppgiften att ta fram förslag till nordiska projekt och aktiviteter med målet att minska ojämlikhet i hälsa. Samarbetet ska främst fokusera på preventiva åtgärder för att minska ojämlikhet i hälsa genom att granska olika livsstils- 
faktorer såsom alkohol, tobak, diet, kost, motion etc. Ett exempel på en aktivitet kan vara en kampanj för att bekämpa den nya folksjukdomen fetma. Gruppen bör också ha en beredskap för att arbeta med frågor som Nordiska ministerrådet föreslår.

Plattformen bör bestå av deltagare med politiskt mandat, praktiker, forskare samt tjänstemän. Ett tvärsektoriellt perspektiv ska vara en ledstjärna för plattformen som också ska samverka med befintliga arbetsgrupper, nätverk, institutioner etc. på den nordiska nivån.

\section{Patientrörlighet}

\section{Förslag $7 \quad$ Patientrörligheten inom Norden}

\section{De nordiska länderna bör till nästa års ministermöte utvärdera effekterna för patienterna av de nordiska ländernas nyligen beslutade implementering av EU:S patientrörlighetsdirektiv och pröva att ytterligare vidga rättigheten att få vård i något av de andra nordiska länderna.}

\begin{abstract}
Det är naturligtvis värdefullt för patienter att kunna välja vårdgivare. Det gäller inte enbart inom den egna kommunen och det egna landet utan också i något av de andra nordiska länderna. Det finns också ett värde i att kunna söka och vid behov få vård i något annat europeiskt land. EU har antagit ett direktiv om patientrörlighet som rör EU-länderna samt Norge, Island och Schweiz.
\end{abstract}

De nordiska länderna har var för sig antagit lagar för att implementera direktivet. De olika lagarna skiljer sig åt.
Det är tillåtet för de nordiska länderna att införa en än större grad av valfrihet för nordiska medborgare så länge detta inte innebär en försämrad nivå för övriga EU-medborgare än den som EU-direktivet ger.

Det är inte nu, efter enbart några månader, möjligt att bedöma hur de nordiska ländernas införande av direktivet påverkat medborgarnas reella valfrihet. Därför föreslås att en ökad valfrihet prövas av ministrarna efter ytterligare ett års erfarenhet av implementeringen. 


\section{Hälsa och teknologi}

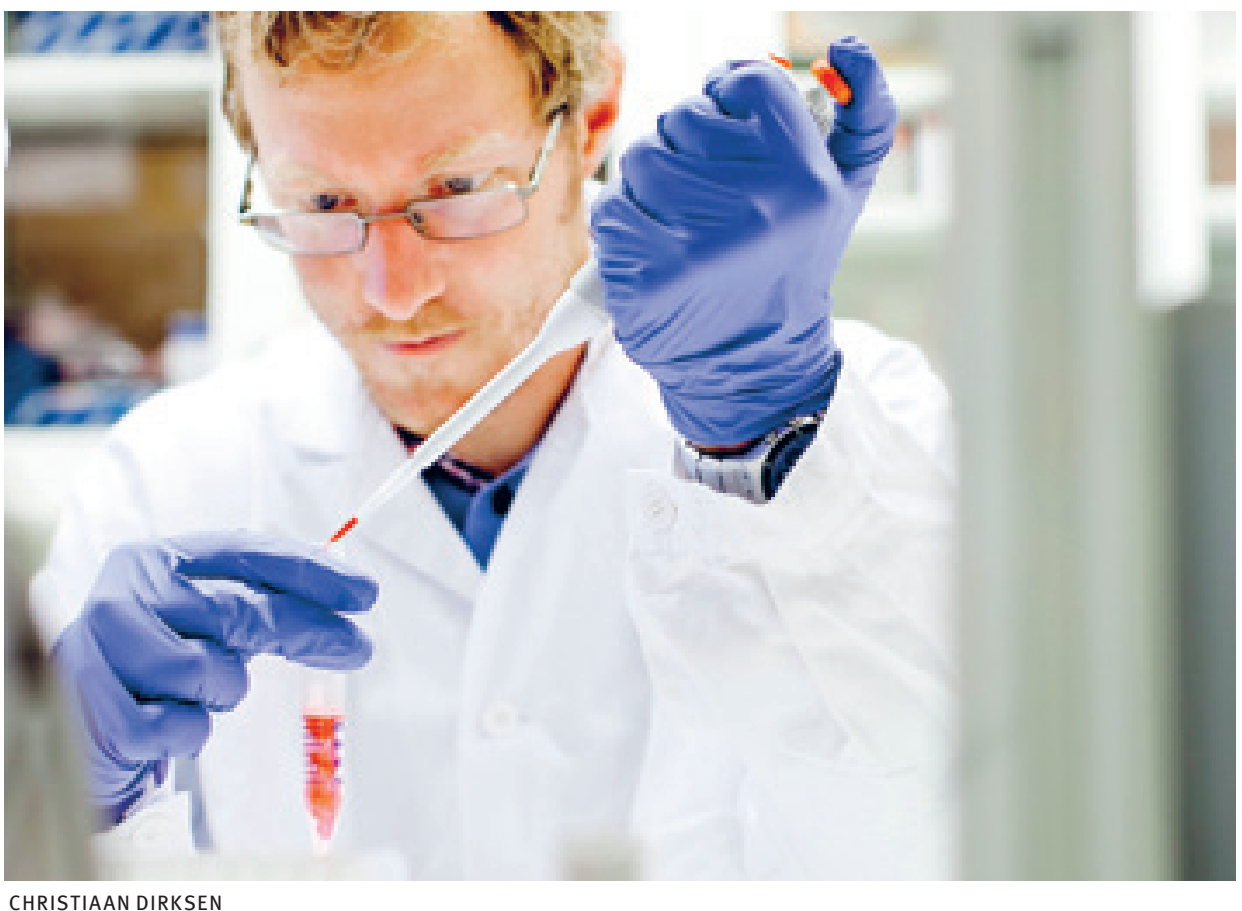

\section{Förslag 8 Förstärkt samarbete om välfärdsteknologi}

Det utarbetas en gemensam nordisk definition för välfärdsteknologi. En gemensam nordisk marknad förstärks genom att standarder för välfärdsteknologiska produkter harmoniseras och gemensamma riktlinjer tas fram. Brukarnas inkludering i utvecklingsarbetet inom välfärdsteknologi främjas med hjälp av informationsförmedling, goda exempel och gemensamma riktlinjer.

En definition av välfärdsteknologi är t.ex. kunskap om och användandet av teknik som kan bidra till ökad trygghet, aktivitet, delaktighet och självständighet för personer med funktionsnedsättning och deras anhöriga, inklusive de äldre. Enligt en bredare definition handlar det dock om tekniska lösningar som underlättar livet och ökar delaktigheten för mycket större grupper av medborgare. Formerna kan vara många; vård, hjälpmedel, lösningar i bostäder, rehabilitering, specialundervisning, tillgängliga arbetsplatser eller individanpassad kommunikation. Universell utformning är ett begrepp, varigenom man strävar efter att bygga ett lätt tillgängligt och hållbart samhälle för alla. Arbetet är ofta tvärsektoriellt och det är viktigt att se hälso- och socialsektorerna som en och samma helhet. 


\section{En nordisk definition av välfärds- teknologi}

Välfärdsteknologi är högt prioriterad i hela Norden, men länderna har valt att arbeta med temat ur litet olika synvinklar. De nordiska länderna har bytt erfarenheter och information om välfärdsteknologi under de senaste åren och det pågår sam. arbete t.ex. gällande innovationer och hur de kan tas i bruk mera effektivt. Nordiska ministerrådet har också påbörjat ett projekt som bygger upp nordiskt samarbete på kommunnivå. Det saknas dock fortfarande en gemensam, allmänt accepterad och samnordisk definition på välfärdsteknologi, vilket skulle underlätta samarbetet och göra det mera målinriktat. Därför föreslås framtagandet av en nordisk definition på området.

\section{En gemensam nordisk marknad för standarder för välfärdsteknologiska produkter}

Efterfrågan för välffärdsteknologiska produkter är som högst någonsin och det har redan uppstått hundratals nya arbetsplatser inom branschen. Vad gäller utvecklandet av nya lösningar kunde man dock sträva efter en mycket enhetligare marknad i Norden. Om länderna hade likadana standarder för nya produkter, speciellt på de områden som redan är internationellt starka, skulle de från början få större efterfrågan och volym. Sverige leder för tillfället t.ex. EU-samarbetet gällande standardisering av trygghetslarm.
Välfärdsteknologiska lösningar kräver också i högsta grad samarbete mellan den offentliga och privata sektorn. Det är därför viktigt att inkludera standarder $\mathrm{i}$ anbudsmaterial vid offentlig upphandling på ett likadant sätt i hela Norden. Det nordiska samarbetet kunde som bäst främja verksamheten inom Norden men också leda till en konkurrensmässig fördel på den globala marknaden. Mot den bakgrunden föreslås en förstärkning av gemensam nordisk marknad för standarder för välfärdsteknologiska produkter.

\section{Brukarna ska inkluderas i utvecklings- arbetet inom välfärdsteknologi}

En annan aspekt i samarbetet med välfärds teknologi är att engagera de personer, som själva använder ny teknologi, i arbetet. Nya teknologiska lösningar går ofta in i den privata sfären i och med en ny design av bostäder eller individualiserad teknologi. Det är viktigt att vara öppen till etisk debatt och bearbeta personliga hinder och attityder, både hos dem som använder ny teknologi och hos dem som arbetar med den. Norden kunde gå i spetsen vad gäller inkludering av brukarna i utvecklingsarbetet. Det är viktigt att arbeta lokalt, oftast på kommunal nivå, och samarbete behövs likaväl på nationell nivå. Det nordiska samarbetet kunde fokusera på informationsförmedling, bästa praxis och gemensamma nordiska riktlinjer för inkludering av brukarna. 


\section{Förslag 9 Utökat samarbete om eHälsa}

\section{Samarbete kring e-recept bör fortsätta i nordisk regi. Ett nordiskt hälsobibliotek (online) skapas. Ett nordiskt sökverktyg "Min Patient" utvecklas.}

Med eHälsa menas vårdutövande med hjälp av elektroniska processer och kommunikation. Begreppet kan omfatta en rad tjänster såsom e-journaler, telemedicin och hälsoinformation för patienter. eHälsa ska ses som holistisk moderniseringsverksamhet i stället för enbart nya teknologiska lösningar.

\section{Fortsatt samarbete kring e-recept i Norden}

De nordiska länderna har deltagit aktivt $\mathrm{i}$ EU-samarbete inom eHälsa, t.ex. epSOSprojektet. Syftet har varit, att utveckla europeiska eRecept, som underlättar medborgarnas rörlighet över landsgränserna trots deras behov för medicinering. EU projektet är nu slut men ett nordiskt samarbete bör ta vid. De nordiska länderna samarbetar också om gemensamma strukturer och terminologi i patientjournaler, indikatorer för att jämföra och mäta utvecklingsarbetet inom eHälsa samt kartläggning av juridiska hinder för landsöverskridande verksamhet.

\section{Ett gemensamt nordiskt hälsobibliotek (online)}

En relativt ny idé, som har kommit längst i Norge, är ett hälsobibliotek som fungerar online. Biblioteket ger service för professionella inom hälsovården i form av goda exempel, anvisningar till behandlingsprocedurer, informationsdatabaser och tid- skrifter. Det mesta av innehållet är dock öppet för alla medborgare. Motsvarande verksamhet finns i andra länder, men syftet och referensramarna varierar. Det är en gemensam trend i Norden, att patienterna ska ha lättare tillgång till information om kvalitet och medicinska resultat och online-service, som riktar sig direkt till medborgarna. Samarbetet kring hälsobiblioteket skulle vara kostnadseffektivt, ge all vårdpersonal tillgång till vetenskaplig information och dessutom bidra till att öka medborgarnas kunskap och ansvar för sin egen hälsa.

\section{Ett nytt nordiskt samarbete kring sökverktyget "Min Patient"}

Inom ramen för online biblioteket kan idén om ett verktyg "Min Patient" utvecklas. Det handlar om att etablera en intelligent sökfunktion som erbjuder stöd för läkaren i hans/hennes individuella bedömningar av patientens vårdbehov. I praktiken går det till så, att läkaren skriver in patientens symptom utan att röja patientens identitet och får som svar ett flertal patienter med samma symptom samt en anvisning om förslag till vård. De flesta länder har utvecklat sin datainsamling om patienter och vård till den grad, att en dylik sökfunktion kunde utvecklas. En sådan sökfunktion skulle öka patientsäkerheten och därigenom bidra till ökad tillit till vården. 


\section{Psykiatri}

\section{Förslag 10 Stärkt nordiskt samarbete inom psykiatriområdet}

\section{Det nordiska samarbetet om psykiatri stärks genom ett årligt återkommande nordiskt toppmöte inom psykiatri- området, ökad nordisk kunskapsinsamling och erfaren- hetsutbyte om modeller för bästa praxis.}

När människor drabbas av psykisk ohälsa, får det ofta stora mänskliga konsekvenser både för den enskilda individen och för de anhöriga. Allt fler invånare i Norden diagnosticeras med en psykisk störning. Det gäller i synnerhet barn och unga och det gäller icke-psykotiska störningar. De nordiska länderna upplever alltså att psykisk ohälsa står för en växande andel av den totala sjukdomsbördan och den tar många resurser i anspråk inom hälsovården, sjukvården och den sociala omsorgen. Att mentala hälsoproblem och psykiska störningar ökar allt mer får därför stora samhällsmässiga konsekvenser för de nordiska länderna - bland annat eftersom psykiska problem även är en stor bidragande orsak till sjukfrånvaro, långtidsarbetslöshet och förtidspensionering.

Systematisk statistik på förtidspensioneringar på grund av psykisk sjukdom i Norden saknas och det finns skäl att se närmare på området. En undersökning utförd år 2009 av finska Folkpensionsanstalten kan dock visa på att fem finska ungdomar förtidspensioneras dagligen på grund av en psykisk sjukdom, samt att närmare hälften av alla förtidspensionerade i Finland blir förtidspensionerade på grund av en psykisk sjukdom. Totalt sett var det frågan om 117600 personer $i$ 2009. Hälften av dessa blev förtidspensionerade på grund av depression. Mellan 2004 och 2009 växte andelen förtidspensionerade män med psykisk diagnos med $60,5 \%$ och andelen kvinnor med $42,1 \%$.
Den största ökningen var bland dem under 30 år. Liknande tendenser, särskilt bland unga under 30 år, kan ses i de andra nordiska länderna.

En psykisk diagnos har också konstaterats vara den främsta orsaken till att en ung person beviljas förtidspension av något slag. Detta gör sig gällande i över hälften av fallen i alla nordiska länder, samt i upp till $80 \%$ av fallen i Danmark och $76 \%$ i Sverige.

De nordiska regeringarna erkänner behovet av att likställa psykiatriska sjukdomar med fysiska sjukdomar. Under dessa år utvecklas även behandlingsutbud och behandlingsmetoder inom psykiatrin i stor utsträckning med fokus på bland annat förebyggande arbete, en mer sammanhängande behandling och större involvering av individen, minskad användning av tvång, avstigmatisering och den enskilde patientens möjlighet att bli helt eller delvis frisk efter sjukdomen. Fokus ligger även i större utsträckning på den hälsomässiga ojämlikhet som människor med psykiska störningar upplever - människor med psykiska störningar drabbas nämligen i högre grad av fysisk sjukdom än resten av befolkningen.

Samtidigt är psykiatrin ett område som präglas av låg eller bristande evidens. Ökad forskning och utveckling är en förutsättning för att ett verkligt kvalitetslyft kan ske inom den psykiatriska behandlingen. Det finns behov av att utveckla och sprida evidens- 
baserade metoder så att behandlingen $\mathrm{i}$ större utsträckning bygger på den bästa kunskap som finns att tillgå för tillfället.

När vi står inför dessa utmaningar - och med tanke på de nordiska ländernas många gemensamma drag vad gäller samhällsuppbyggnad och samhällsutveckling - är det givet att det nordiska samarbetet om psykiatri ska stärkas så att länderna i större utsträckning kan dra nytta av de erfarenheter som deras nordiska grannar gör. Detta samarbete kan fokusera på:

- Ökat erfarenhetsutbyte om modeller för bästa praxis så att erfarenheter som gjorts i ett nordiskt land kan gynna andra invånare i Norden, till exempel genom att nya behandlingsmetoder kan börja användas efter att ha testats i ett annat nordiskt land eller genom ökat samarbete om att testa nya behandlingsmetoder.

- Ökad nordisk kunskapsinsamling genom ett utvidgat forskningssamarbete samt ett ökat samarbete om kvalitetsmätning och utveckling av kvalitetsindikatorer. År 2011 konstaterade ett nordiskt samarbete om kvalitetsmätningar inom psykiatrin att de nordiska länderna har enastående möjligheter för kvalitetsmätning bland annat tack vare ländernas välfungerande kvalitetsregister. Detta samarbete kan med fördel fortsätta och stärkas.

- Ett årligt återkommande psykiatritoppmöte. Ett psykiatritoppmöte som hålls varje år kommer att vara ett givet forum för att utbyta erfarenheter och sprida kunskap och resultat inom psykiatrin (se ovanstående förslag). Ett psykiatritoppmöte där beslutsfattare, forskare, praktiker, brukarorganisationer m.fl. deltar kommer samtidigt att kunna bidra till att rikta fokus mot och medverka till en avstigmatisering av människor med en psykiatrisk störning. 


\title{
Hälsoberedskap
}

\section{Förslag $11 \quad$ Utökat mandat för samarbete inom hälsoberedskapsområdet}

\author{
Den nordiska hälsoberedskapsgruppen (Svalbardgrup- \\ pen) ska få ett utökat mandat. Alla aspekter inom ramen \\ för hälsoberedskapssamarbete ska inkluderas.
}

De nordiska hälsovårdsministrarna undertecknade ett ramavtal om nordiskt hälsoberedskapssamarbete i juni 2002. Avsikten med avtalet var att genom förhandsåtgärder utveckla de nordiska ländernas gemensamma beredskap att förebygga och hantera kriser och katastrofer. Den informella arbetsgruppen (Svalbardgruppen) fick som uppgift att utveckla samarbetet. Avtalet beaktar förutom handläggandet av konsekvenserna av konventionella olyckor speciellt händelser med biologiska och kemiska ämnen, samt behov av specialkunskap vid olyckor med radioaktiv strålning samt terrorattacker.

Svalbardgruppens arbete har i vissa delar fungerat mycket bra, framförallt beträffande nätverkssamarbetet. Arbetsgruppen har dock haft vissa svårigheter med att utföra sina uppgifter framförallt beroende på att det är många myndigheter/institutioner involverade på nationell nivå med olika perspektiv och mål. Under senare år har fokus skiftat från det ursprungliga mandatet till flera andra områden relaterade till katastrofer t.ex. traumavård, ambulansservice och sjukvårdstjänster.
Det är viktigt att utvidga hälsoberedskapen ur ett heltäckande säkerhetsperspektiv. Nya hotbilder växer fram med stor hastighet, inte minst med hjälp av den digitala utvecklingen. Till exempel kräver beredskapen inför olika cyberhot ett intensivt samarbete mellan olika branscher på nationell, nordisk och internationell nivå.

Mandatet behöver dessutom spegla det arbete som faktiskt pågår. Det ständigt ökande antalet allvarliga händelser som har ägt rum under senare tid förstärker motiveringen för ett tätare samarbete ytterligare. Det är av stor vikt att det nya mandatet innehåller en tydlig ansvarsfördelning för samarbetet med Svalbardgruppen och myndigheter/institutioner i de nordiska länderna.

Ett framtida samarbete på hälsoberedskapsområdet kan bland annat handla om gemensam forskning och utveckling, utbildningar, inköp och beredskapslager. Några konkreta exempel är gemensamma flygmedicinska utbildningar och gemensamma resurser för luftburen medicinsk evakuering. 


\section{Läkemedel}

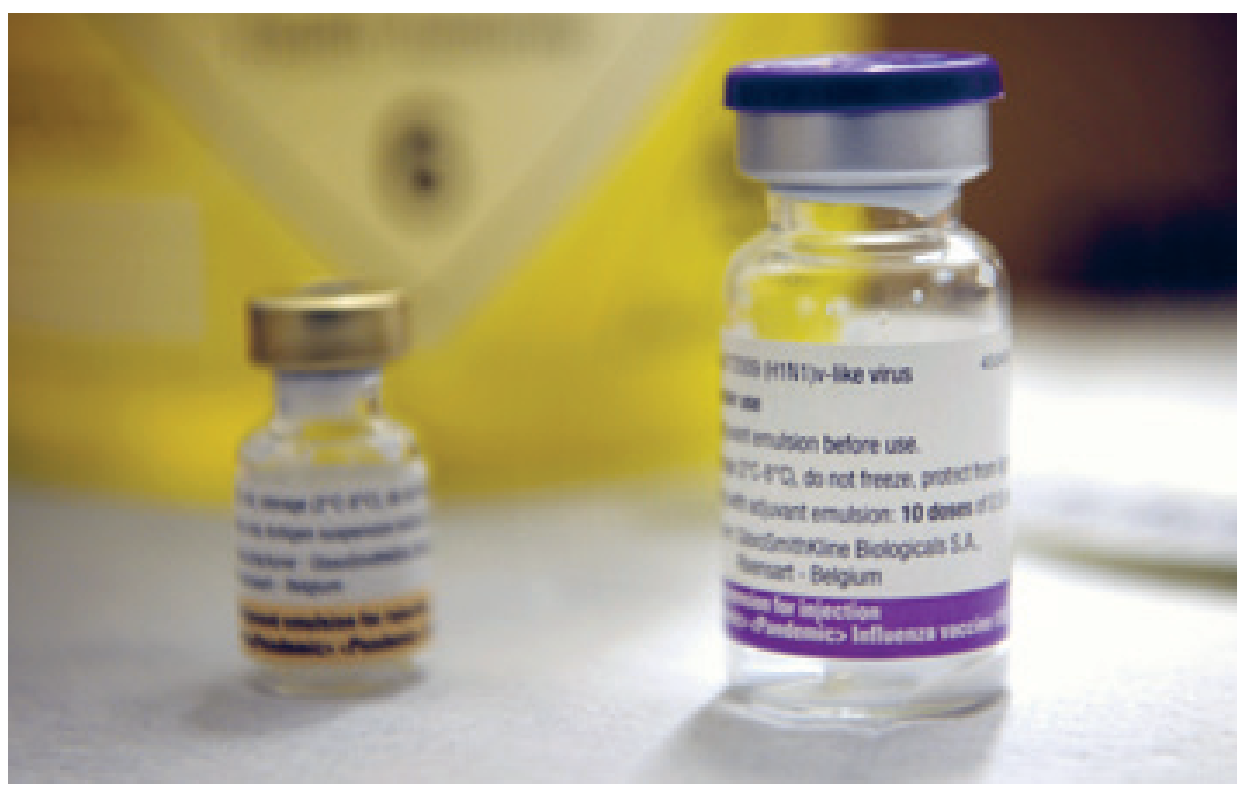

JOHANNES JANSSON/NORDEN.ORG

\section{Fôrslag 12 Utbyggt nordiskt läkemedelssamarbete för högre kostnadseffektivitet och bättre säkerhet}

Det nordiska samarbetet på läkemedelsområdet utvidgas genom etableringen av ett gemensamt apotek för ovanliga läkemedel och utökat samarbete om sällsynta läkemedel samt genom ökat informationsutbyte om inköpsavtal och om tillämpningen av nya läkemedel.

Kostnader för läkemedel står för en stor del av ländernas hälso- och sjukvårdsutgifter. De nordiska länderna ligger alla under OECD-genomsnittet om man ser på läkemedelsutgifterna per invånare eller som andelen av BNP. År 2011 stod läkemedelsutgifterna i OECD-länderna i genomsnitt för gott och väl en sjättedel av ländernas utgifter för hälso- och sjukvård, vilket gör den till den tredje största utgiftsposten i hälso- och sjukvårdsbudgeten näst efter sjukhusvård och primärvård.
Liksom alla andra länder utmanas de nordiska länderna av att nya - och ofta mycket dyra - läkemedel konstant introduceras på marknaden, något som ofta är till stor nytta för patienterna, men som sätter press på ländernas hälso- och sjukvårdsutgifter. Samtidigt innebär den geografiska närheten och språkgemenskapen att skillnader i ländernas tillämpning av nya läkemedel lätt omtalas i de olika nationella medierna, vilket kan pressa hälsovårdsmyndigheterna att följa grannländernas beslut. 
I ett globalt sammanhang är de nordiska länderna var för sig små marknader för läkemedelsproducenterna - särskilt vad gäller läkemedel för behandling av sällsynta sjukdomar. Mot den bakgrunden har möjligheten för ett utvidgat nordiskt samarbete på området diskuterats flera gånger i Nordiska ministerrådets regi - bland annat på isländskt initiativ år 2008 och på ministermötet under det danska ordförandeskapet år 2010. Diskussionerna har emellertid inte lett till några konkreta resultat på grund av skillnader i ländernas organisering inom läkemedelsområdet, vilket bland annat leder till olika prissättningar och olika strukturer för beslutsfattande.

Det finns dock fortfarande möjlighet att utvidga det nordiska samarbetet på läkemedelsområdet som kan gynna invånarna i Norden. Ett ökat informationsutbyte om de villkor och priser som länderna får i samband med inköpen förväntas ge länderna en starkare position i framtida förhandlingar.
Det finns även ett behov av att utvidga informationsutbytet om tillämpningen av nya läkemedel, något som eventuellt i ett senare skede kan utvecklas till ett verkligt samarbete kring bedömningen av nya läkemedel. Samarbetet etableras mellan de relevanta organen i länderna. Oberoende av de hinder som finns för allmänna gemensamma inköp, så skulle det även vara ändamålsenligt att utvidga samarbetet om att upprätthålla ett lämpligt beredskapslager av ovanliga läkemedel. Här avses sjukdomar som förekommer så sällan i de nordiska länderna (t.ex. ormgift, difteri och botulism) att det inte är lämpligt ur ett effektivitetsperspektiv att bygga upp egna nationella lager.

Samarbetet kan först resultera i att ett nordiskt apotek etableras för ovanliga läkemedel och sedan utvidgas till att omfatta beredskapsprodukter, dvs. vacciner och antitoxiner som sällan används, men för vilka de nordiska länderna bör ha ett beredskapslager som kan användas i krissituationer (t.ex. vaccin mot koppor). 


\section{Tjänstemannautbyte}

\section{Förslag 13 Nytt nordiskt tjänstemannautbyte - Pilotprojekt}

\section{Ett förstärkt nordiskt tjänstemannautbyte på hälso- området ska etableras. Fler tjänstemän på departemen- ten ska ges möjlighet till korta utbyten för att skapa fler och bättre nätverk för att öka nordisk kompetens och konkurrenskraft.}

Det nuvarande nordiska tjänstemannautbytesavtalet grundades 1979 och ger statligt anställda möjlighet att lära känna förvaltningen i ett annat nordiskt land, inklusive Färöarna, Grönland och Åland, än hemlandets under en kortare eller längre tid. Tjänstemannautbytet är ett skolexempel på nordiskt samarbete och har under årens lopp fått mycket goda utvärderingar. Noteras bör att utbytet inte kräver något ömsesidigt byte av arbetsplats mellan två anställda och att deltagarna är tjänstlediga med lön. Syftet med utbytet är att lära känna förhållandena i de nordiska grannländerna vilket leder till att det nordiska samarbetet fördjupas och att de nordiska offentliga verksamheterna och deltagarna själva utvecklas positivt.

Dessvärre kan konstateras att det är alltför få tjänstemän som deltar i utbytestjänstgöring. Endast 47 personer deltog i utbytestjänstgöringen under 2013 och av dessa var endast ett fåtal från något departement. Det är framförallt myndigheter av olika slag som skickar ut sina anställda till grannländerna.
Genom att öka förutsättningarna för bättre kontakter mellan ansvariga departement föreslås därför ett tilläggsavtal till det nuvarande tjänstgöringsavtalet. Satsningen bör ses som ett pilotprojekt (3 år) och målgruppen är tjänstemän som arbetar med hälsofrågor på berörda departement. Målet är att skapa fler och bättre nätverk i och mellan berörda departement i de nordiska länderna för att öka nordisk kompetens och konkurrenskraft. Mot den bakgrunden föreslås en kortare utbytestjänstgöring på en till två veckor där fokus ska ligga på att bygga nätverk och därmed bidra till bättre kommunikation och erfarenhetsutbyte mellan länderna. I dag är perioden för utbytestjänstgöringen mellan en till tolv månader, vilket i sig kan vara ett hinder för många arbetstagare respektive arbetsgivare.

En kortare vistelse bör därför ge möjlighet för fler tjänstemän att delta i programmet. Finansiering av pilotprojektet bör belasta Nordiska ministerrådets budget. 


\section{Nationella experter i EU}

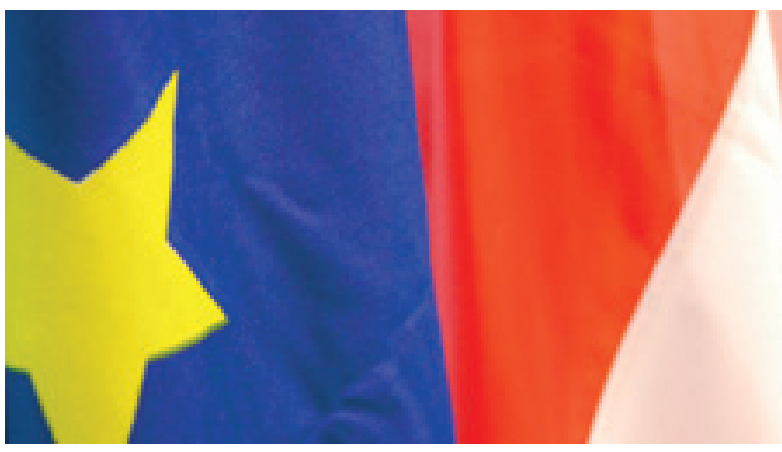

SILJE BERGUM KINSTEN/NORDEN.ORG

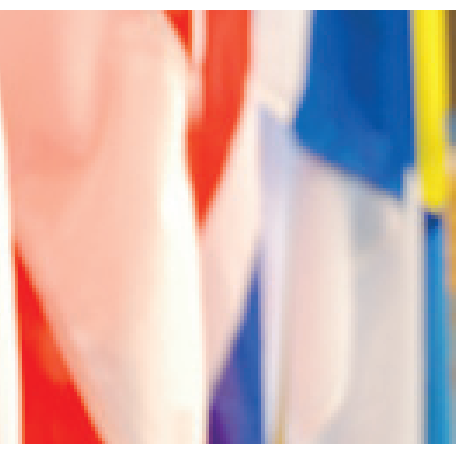

Förslag 14 Nordiskt samarbete om nationella experter

\section{Ett nytt informellt samarbete om placering av nationella experter i Europeiska kommissionen ska initieras på social- och hälsoområdet}

Det nordiska samarbetet baseras på gemensamma värderingar som utgör fundamentet i den nordiska välfärdsmodellen. Välfärdsstaten uppfattas idag som satt under press, inte minst mot bakgrund av den demografiska utvecklingen och den ekonomiska krisen. Därför måste länderna agera tillsammans för att möta utmaningarna. Mot den bakgrunden föreslås ett nytt nordiskt informellt samarbete om placering av nationella experter i Europeiska kommissionen inom social- och hälsoområdet (DG EMPL och DG SANCO).

Alla länder (inklusive EES-länderna) skickar experter till EU:s institutioner. För närvarande har t.ex. Sverige ca 30 experter totalt som täcker alla politikområden, dock inga på social- och hälsoområdet.

En nationell expert inom kommissionen ökar inflytande över pågående processer. Experten kan t.ex. påverka utformningen av ett förslag, informellt sprida information och är därigenom en stor tillgång för hemlandet. Ett informellt sam- arbete mellan de nordiska länderna skulle kunna innebära en bättre och jämnare placering av nationella experter och därmed en bättre användning av ländernas resurser. Det bör vara mer effektivt att ha nordiska experter jämnt spridda i olika enheter än flera experter med samma/liknande syn vid en enhet. En nationell expert vid kommissionen innebär en relativt stor kostnad för ett departement vilket begränsar ländernas möjligheter till mer inflytande på ett tidigt stadium. Experten får sin lön från arbetsgivaren (departement eller myndighet) och kostnadsersättning från EU-institutionen (traktamente och ersättning för resor till och från tjänstgöringsorten).

Ett första steg i det nya samarbetet kan vara att ÄK-S informeras om vilka nationella experter som tjänstgör i kommissionen från respektive land. Därefter bör de internationella sekretariaten vid de nordiska social- och hälsodepartementen träffas regelbundet för att diskutera planläggning av det informella samarbetet. 



\section{norden}

Nordiska ministerrådet

Ved Stranden 18

DK-1061 Köpenhamn K

www.norden.org

\section{Det framtida nordiska hälsosamarbetet}

Bo Könberg har skrivit en oberoende rapport - Det framtida nordiska hälsosamarbetet. Rapporten innehåller konkreta förslag på hur det nordiska samarbetet kan utvecklas och stärkas under de närmaste fem till tio åren. Rapporten presenterades för första gången i samband med de nordiska social- och hälsoministrarnas möte på Island den 11 juni 2014.

Bo Könberg är en svensk, liberal politiker och var sjukvårds- och socialförsäkringsminister 1991-1994. Han ledde då arbetet med den svenska pensionsreformen. Han har deltagit i ett flertal svenska utredningar inom välfärdsområdet, bland annat ÄDEL-reformen och Vårdavgiftsutredningen.

Rapporten ingår i Nordiska ministerrådets program Hållbar nordisk välfärd, en av ministerrådets största satsningar under perioden 2013-2015. www.norden.org/valfard 